\title{
Application Of Models Of Group Investigation In The Diversity Of Natural And Artificial Disposal Materials To Improve The Results Of IPS Study In The Class V A Of SDN Kepuh Of 2 Waru
}

\author{
Muslikha \\ Universitas Negeri Surabaya \\ Surabaya, Indonesia \\ muslikha67@gmail.com
}

\begin{abstract}
The purpose of this research is to know: 1) Application of Group Investigation model on the material of diversity of natural and artificial appearance. 2) Identify the increase in student learning activity at the time of application of Group Investigation model 3) Analyze the improvement of student learning outcomes after the application of Group Investigation model.

This study uses action research because of classroom action research. In this study, the subject of the study were 32 students of class V A SDN Kepuh Kiriman 2 Year Lesson 2018/2019. Methods of data collection in this study are observation, test, and field notes. Data analysis techniques use data reduction, data presentation, conclusion drawing, and reflection verification.

Based on the observation, in the first cycle average of 76.25 completed there are 20 students $(62,5 \%)$, on second cycle average 84,69 and in the second cycle which complete there are 30 students $(93,75 \%)$. The second cycle is more interesting with additional power point. The average value of learning quality in the first cycle is 3.00 and the second cycle is 4.00 . Thus the quality of learning from before the action up to the second cycle is increased.
\end{abstract}

Keywords-Group Investigation; Natural Appearance; Learning Outcomes

\section{INTRODUCTION}

Social Sciences material needs to be conveyed with learning models and innovative and creative approach strategies, one with the Group Investigation which is expected to increase the ability to participate in democratic social processes through understanding interpersonal, intrapersonal, and academic skills. [1].

Studies of social studies learning in elementary schools have been widely carried out, but still, have low priority [2], and the reality that occurred in SDN Kepuh Kiriman 2 when learning the diversity of natural and artificial features is very apparent that students are reluctant to pay attention to the teacher's explanation. This research is motivated because the students are passive in learning, and so far, the learning method chosen by the teacher has not been able to improve the learning outcomes of students in the learning material of natural and artificial appearance diversity.
At present, the Indonesian government carries out development in all fields, including education, which is directed at the demands of community needs and the development of the times. To make changes in teaching and learning activities to be more attractive to students and can improve learning outcomes, namely the implementation of cooperative learning models [3]

Students should be active in their own learning and the teacher supports and facilitates learning [4].

Group Investigation is one of the effective ways to explore the ability of students in social studies learning, especially to explore the lessons of natural and artificial appearance diversity. This allows a class to work actively and cooperatively in small groups and provides opportunities for students to play a more active role in determining their own learning process goals [5]. Teachers still apply conventional models and do not vary which makes participants students are bored and saturated with social studies subjects. Based on the description of the previous background, the researcher can present the formulation of the problem as follows. 1) How is the implementation of the Group Investigation model on the material diversity of natural appearance and made in class V A SDN To the Submission of 2 Waru? 2) Is the implementation of the Group Investigation model able to increase the activity of participants when learning the diversity of natural appearance and made in class V A SDN To the Submission of 2 Waru? 3) Does the implementation of the Group Investigation method improve student learning outcomes when learning the diversity of natural and artificial features in class V A SDN To the Submission of 2 Waru?

The aim to be achieved in this study is to find out: 1) Application of the Group Investigation model on the material diversity of natural appearance and made in class V A SDN Kepuh Submission of 2 Waru. 2) Identify an increase in student learning activities at the time of applying the Group Investigation model on material diversity in natural appearance and made in class V A SDN Kepuh Submission of 2 Waru. 3) Analyzing the improvement of student learning outcomes after the application of the Group Investigation model on material 
diversity in natural appearance and made in class V A SDN Kepuh Submissions 2 Waru.

\section{THEORY STUDY}

The concept of learning according to Corey [6] is the process of managing one's environment intentionally in order to participate in certain behaviors, and conditions specifically or produce responses to certain situations. Dimyati and Mudjiono [6] argue learning is an activity that is carried out by the teacher in a planned and programmed manner in instructional models, in order to make learning active, with emphasis on providing learning resources. Law No. 20 of 2003 National Education System Article 1 paragraph 20 Learning is a process of reciprocal relations between educators and students as well as learning resources in a learning environment. Sudjana [7] states that learning can be interpreted as a systematic effort and intentional to create so that there is an educational interaction between two parties, namely students as learning citizens and educators as learning resources that conduct learning activities.

Learning as a component of educational science related to the purpose and reference material of good relations that are explicit or implicit [6]. Learning is a form of a person's behavior or personal change process based on a particular experience or practice [6]. A business process carried out by a person to produce new behavioral changes as a whole as a result of his own experience in interacting with his environment is the notion of learning [8]. Learning is a process of knowledge formation [9].

Sudjana [7] suggests that learning outcomes are behavioral changes that cover the cognitive, affective, and psychomotor fields that are possessed by students after receiving the learning experience. Learning outcomes are changes in students' behavior due to learning [10].

In general, cooperative learning is more directed at teachers who assign tasks and questions and provide material and information designed to help students solve problems [1]. Cooperative learning is a learning model that encourages students to exchange ideas with their groups in understanding the content of learning material. Slavin in Isjoni [11] cooperative learning is a teaching and learning activity that divides students into small groups and collaborates collaboratively with 5 members with different group structures. Based on the condition of students, the strategy could be used to overcome the learning problem above is a problem-solving strategy [12]. Opinions expressed by Johnson [13]. There are five elements of this cooperative learning model namely the element of positive interdependence between students.

Suprijono [1] argues that cooperative learning is a broader concept covering all types of group work including Group Investigation type cooperative learning. Finally, they produce joint studies, Students are given awards according to achievements in groups and individual studies [14]. All these activities are scientific systemic activities starting from collecting data, synthesizing, reaching conclusions [1]. The problem-solving phase that is related to the process of answering questions, what is the nature of the problem, and what is the focus of the problem. The classroom management stage is related to the process of answering questions, what information is needed, how to organize groups to obtain the information. While the meaning stage refers to the process of assessing how the group lives up to the conclusions it makes, as well as what distinguishes a person as a result of following the process. Operational Framework of Josie and Weil Group Investigation [15].

Group Investigation learning models also have some drawbacks, namely: a) material delivered at one small meeting b) difficult to give a personal evaluation, c) not all topics match the GI learning model, GI learning model is suitable for application to a topic requires students to understand a discussion from their own experiences, d) Group discussions that are less effective, e) students who do not fully understand the material prescriptions will experience difficulties when using this model [16].

The action hypothesis in this study is through the application of the Group Investigation Model on the diversity of natural and artificial appearance material can improve the learning outcomes of social studies in class V A SDN Kepuh Submissions 2 Waru. 1) The application of Group Investigation type cooperative learning can make learning more meaningful. 2) There is an increase in student learning activities during the implementation of Group Investigation cooperative learning, 3) There is an increase in student learning outcomes after the application of Group Investigation type cooperative learning on the diversity of natural appearance material and made in class V A SDN Kepuh Submissions 2 Waru.

\section{RESEARCH METHODS}

This type of research uses classroom action research. Arikunto [17] states that CAR is a reflection of learning activities in the form of an action, which is deliberately raised and occurs in a class simultaneously. The subjects in this study were determined based on certain considerations. The consideration of the learning feasibility of utilizing Group Investigation in learning the diversity of natural and artificial appearance material.

The research subjects were Class V A SDN students Kepuh Shipment 2 Academic Year 2018/2019. The total number of students in grade V A SDN Kepuh Kiriman 2 is 32 students. The place of the research activity was conducted in SD Negeri Kepuh Kiriman 2, namely, in class V A. the time of the research was carried out in the odd semester of 2018/2019 school year.

Data collection techniques in this study are observation and tests. The research instruments in this study were observation sheets and test questions. At this stage, the data analysis techniques used are data reduction, data presentation, conclusion drawing, and reflection verification.

\section{RESEARCH RESULTS}

Based on observations, in the first cycle an average of 76.25 completed there were 20 students $(62.5 \%)$ who did not complete there were 12 students $(37.5 \%)$, in the second cycle on average 84.69 and in the second cycle that was completed there were 30 students $(93.75 \%)$ who did not complete was 2 students $(6.25 \%)$. The second cycle was more successful 
because the investigation group was made more attractive with additional powerpoints. Utilization Group Investigation Models has improved the quality of learning. The average value of the quality of learning in the first cycle is 3.00 and in the second cycle is 4.00 . Thus the quality of learning from before the action to the second cycle has increased.

\section{CONCLUSION}

The application of the Group Investigation Model on the diversity of natural and artificial features can improve the learning outcomes of social studies in class V A SDN Kepuh Submissions 2 Waru. 1) The application of Group Investigation type cooperative learning can make learning more meaningful. 2) There is an increase in student learning activities during the implementation of Group Investigation cooperative learning, 3) There is an increase in student learning outcomes after the application of Group Investigation type cooperative learning on the diversity of natural appearance material and made in class V A SDN Kepuh Submissions 2 Waru.

\section{REFERENCES}

[1] A. Suprijono, "Model-model pembelajaran emansipatoris," Yogyakarta: Pustaka Pelajar, 2016.

[2] P. G. Fitchett, T. L. Heafner, and P. VanFossen, "An analysis of time prioritization for social studies in elementary school classrooms," J. Curric. Instr., vol. 8, no. 2, pp. 7-35, 2014.

[3] M. Nurtanto, "Implementation of Problem Based Learning to Increase Cognitive, Psychomotor, and Affective Learning Outcomes of Students in Vocational Schools," Vocat. Educ. Journals, vol. 5, p. 3, 2015.
[4] S. Candrasekaran, "Productive Methods of Teaching Middle School Science," Int. J. Humanit. Soc. Sci. Invent., vol. 3, no. 7, pp. 15-25, 2014

[5] B. Untoro, "The Effect of Group Investigation and Learning Style on Students' Writing of Analytical Exposition," IJEE (Indonesian J. English Educ., vol. 3, no. 1, pp. 29-45, 2016.

[6] S. Sagala, Concepts and Meanings of Learning. Bandung: Alfabeta, 2011

[7] N. Sudjana and A. Rivai, "Media pengajaran." Bandung: Sinar Baru Algensindo, 2010

[8] Slameto, Learning and Affecting Factors. Jakarta: Rineka Cipta, 2010.

[9] A. Budiningsih, Learning \& Learning. Jakarta: Rineka Cipta, 2012.

[10] M. Nurtanto and H. Sofyan, "Implementasi problem-based learning untuk meningkatkan hasil belajar kognitif, psikomotor, dan afektif siswa di SMK," J. Pendidik. Vokasi, vol. 5, no. 3, pp. 352-364, 2015.

[11] Isjoni, Cooperative Learning. Yogyakarta: Student Library, 2013.

[12] I. Astra, C. Wahyuni, and H. Nasbey, "Improvement of Learning Process and Learning Outcomes in Physics Learning by Using Collaborative Learning Model of Group Investigation at High School (Grade X, SMAN 14 Jakarta).,” J. Educ. Pract., vol. 6, no. 11, pp. 75$79,2015$.

[13] A. Lie, Cooperative Learning Practices Cooperative Learning in Classrooms. Jakarta: Grasindo, 2010.

[14] N. O. Akcay and K. Doymus, "The effects of group investigation and cooperative learning techniques applied in teaching force and motion subjects on students' academic achievements," J. Educ. Sci. Res., vol. 2, no. 1 , pp. 109-123, 2012.

[15] W. Sektiyono, "Effectiveness of the Group Investigation Type Learning Model on the Mathematical Problem Solving Ability of Class VII Students," Semarang State University, 2014.

[16] N. M. Adora, "Group investigation in teaching elementary science," Int J. Humanit. Manag. Sci., vol. 2, no. 3, pp. 146-147, 2014.

[17] S. Arikunto, Basics of Educational Evaluation. Jakarta: Bumi Aksara, 2012. 